\title{
Turn the Page, Hear Her Shout: Dissident Voices in the Journals of Female Secondary School Students and the Silence of their Male Counterparts
}

\author{
Rachel C. Lallouz * \\ The University of Victoria \\ rachel.c.lallouz@gmail.com
}

\begin{abstract}
This research investigates how a minority of female secondary school students in a Writing 12 class resisted internalization of gender stories by rewriting and subverting those same stories through the process of journaling. Journal material collected from five female students was analyzed using qualitative narrative analysis of quotes that demonstrate rewritten gender stories. The research examines how female students positioned the self as the storyteller, and by doing so, adopted an active role in reconstructing their narrative identities to include traits of strength and resilience. Journal material collected from three male students - the only consenting male students_-revealed an absence of these students directly addressing the concept of gender through writing. The research suggests that for these male students, simply engaging in the project of journaling was a form of resistance against gender stories idealizing an noncompliant, less emotionally active male student and writer.
\end{abstract}

Keywords: Gender story; the self; resistance; shame; space; journaling; identity

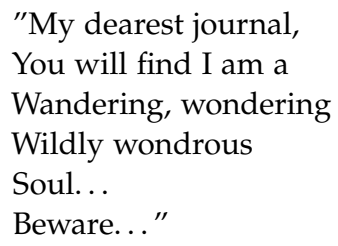

Had not expected to come across such a striking warning when I opened the first journal submitted by one of my Writing 12 students at Victoria High. It reminded me of the scrawled inscriptions many of us mark the very first pages of our diaries with: "THIS IS PRIVATE" or "For my eyes only!" or written on the first page my own journal: "KEEP. OUT. THAT MEANS YOU." This is not to say these journals come without their own physical guards of secrecy, too: locks and keys, or a personal method of mine which entailed leaving the first fifteen or so pages

*I would like to acknowledge my professors from the University of Victoria's 2014 Research Institute for Professional learning: Kristin Mimmick and Allyson Fleming, for reading a very different start of what this paper has become. In particular, I would like to thank Dr. Kathy Sanford, who also supported my pursuit of the Jamie Cassels Undergraduate Research Award. To the student participants from my Writing 12 class: thank you for allowing me more than just a glimpse into your own paper mirrors. 
of my journal blank. This, I felt sure, would throw off the prying eyes of anyone who had gained entry. But if indeed the voyeur had found the journal in its hiding place under the mattress, unearthed the tiny key from the sock drawer, made it past the lock and the first blank fifteen pages, bypassed the pointed finger "YOU" and its directed pang of guilt, what really was within those pages that needed such carefully constructed defences?

Writing that is aware of its own power to affect the reader, that is more concerned with keeping itself contained and unseen and controlled-with keeping something in rather than someone out.

Serena's journal had no lock and key and was given to me with the open invitation to read and analyze its contents. I knew, though, that I had better heed her warning.

The ellipsis gestured, beckoning me to turn the page.

\section{The Study: Structure and Findings}

At the conclusion of my practicum teaching Writing 12 at Victoria High, a public school located in Western Canada, I carried out an inquiry of collected journal material to analyze how female students challenged gender stories or stereotypes about women in their writing. I was also curious to see if they were carrying on the historical practices of using the journal as a space in which to resist (Huff, 2003). At the same time, I wanted to examine the journal material of male students to determine whether they were also using the journal as a space to resist gender stories.

Gender is understood to be a social construct constituted by the repetition of social, embodied practices (Dalley-Trim, 2006). One of these practices is the communication of gender stories, what I define as social and cultural messages relaying how to perform a specific, idealized idea of gender correctly. In this study, I was interested in using a feminist lens to close read any moments in the text where the concept of gender stories surfaced or the subject of gender was approached.

At the beginning of my practicum, students were instructed to find a blank journal or notebook. Students were asked to journal during in-class writing time and at home, for seven weeks. Out of a 31 person class, 19 of the students completed the journal assignment and at the conclusion of the seven weeks, 15 students who consented to participate in the study returned their completed journals to me. Among the 12 female students who participated, only five approached the subject of gender and rewrote gender stories: Jamie, Lisbeth, Cedar, Penny, and Serena. All student names in this paper are pseudonyms.

Each of the five journals I analyzed stand as literary spaces in which gender narratives causing shame, frustration, or pain are transformed. This transformation was completed through "rewriting," defined in this context as the act of reimagining and subverting gender narratives. Each student employed the use of "I," and in doing so, positioned the writing self as the storyteller. By adopting this role, each of the students was calling to an "imagined community" (Huff, 2003) of shared female experience crossing time and space. The storyteller role enabled them to draw from their conceptions of female resistance and continue on a legacy of resistance through writing. As storytellers, students constructed a listening "other" to validate the newly rewritten gender stories they were creating, and to legitimize their own voices of resistance which might otherwise be scrutinized or minimized. Ultimately, the journals demonstrated the inventiveness of a minority of participating female students in their expression of alternative resistance. That only five female students rewrote gender stories illustrates how the majority of my participating female students did not feel the need to resist gender stories, or were resisting by other means. 
Out of the three male students who provided consent-Seamus, Alistair, and Perry-none directly explored the idea of gender or rewrote gender stories. Four male students chose not to write a journal at all. The absence of their voices rewriting gender stories, and their absence participating in the project as whole exposed the effect gender stories have on the performance of male student identity in the classroom-one that is seen as "tough" (Dalley-Trim. 2006) or noncompliant with teacher requests (Leaper \& Brown, 2008), and as enjoying outwardly competitive assignments (Butler, 2014). The male students who participated sought to uphold aspects of the idealized male identities espoused by gender stories. Rather than risk dismantling their carefully manicured identities by engaging in the project of rewriting, these three male students may have chosen a different means of self-preservation, and a different self to preserve.

\section{MethoD}

When the journals from the 15 consenting students were returned to me, I photocopied each consenting student's journal, and examined them for common themes in subject matter. What quickly struck me was the number of female students who used their journals to blatantly accost gender stereotypes and stories. Though these journals represented a minority of student submissions, their voices echoed in my mind long after I had closed the covers.

From those five journals, I pulled from the pages one or two quotes that confront a stereotype or grapple with the issue of gender. I deliberately picked quotes that were visceral and raw, parts of larger streams of consciousness. Penny's quote is the exception, as her exploration of gender and identity occurred most visibly through the subjects and characters in her poetry and fiction, rather than her nonfiction. The quotes included in this paper, though fragments, are complete stories unto themselves. I used Gubrium and Holstein's (2009) version of qualitative narrative analysis as a framework for analysis, treating each quote as its own self-enclosed story and each journal as its own distinct text. Through narrative analysis, I compared these stories for similarities and differences in both form and content (Gubrium \& Holstein. 2009).

When comparing the forms of the stories, I was most concerned with how students were internally organizing their stories, where they were located as subjects of the rewriting, and how technical literary devices of grammar, diction, theme, and tone enabled a reconstruction of a more powerful, active self. Despite similarity in theme between the stories, the content of each rewritten gender story differed drastically from the others in scope and experience. How the female students had been affected by gender stories, and how they were transcribing and rewriting them, varied from student to student. These variations and shades were indicative of the unique experiences of sexism and oppression each student had endured or was enduring.

Narrative analysis takes into account the social context of a narrative (Gubrium \& Holstein 2009). This form of analysis considers how an inner life story has been shaped by the institutional settings the storyteller writes their story from and about (Gubrium \& Holstein, 2009). As much as I examined the form and content of each story, I could not do so without investigating how that form and content came to be developed as a product of its teller. To examine the act of storytelling required me to envision the storyteller, a figure who was actively transforming through the act of writing (Wolgemuth, 2014). I found myself reading the words of the journals and visualizing my changing students. Upon "seeing" each student, I looked past them to the social environment giving rise to their words.

Though I examine specific components of the journals and my focal group is small, it is my hope that this study can provide insight prompting further inquiry into the study of student journal material. As Gubrium and Holstein (2009) note, narrative analysis of select textual samples can contribute to broader knowledge of a group's experience. 


\section{JUSTIFYING FORM}

The form of this writing is "pastiche" or hybrid text, a textual experiment of data, analysis, journal excerpts and memoir woven into a whole (Ely, 1997). My paper's form reflects the form of the journals-an effort on my part to move through the same process as the students while completing my research. In doing so, I hoped to unlock deeper meaning in the very text being analyzed.

The pastiche demonstrates how form affects meaning (Ely, 1997). In this case, the different texts layered together communicate my struggle to piece together a narrative about how others tell their stories. Braided into the students' stories is the story of my research. As Ely (1997) notes, the arrangements of different texts in pastiche produce the distinct texture of an overall narrative. Each separate text- my first memory of data collection or the transcribed journal entry of a student- acts upon the other to create interconnected meanings that the reader may interpret on their own. The multiple forms in this research, which include different forms pulled from the journals themselves, provide a structural "framework" (Ely, 1997) that enables the act of comparison requested of narrative analysis.

Pastiche has allowed me to present multiple realities, consciousnesses, and portraits of time to the reader. Included are the verbatim journal quotes of students and my own memories of teaching the class and completing this research. The memories I include, written in past and present tense, appear in this paper following an asterisk. These memories locate me in the text, providing glimpses as to what spurred my research. The inclusion of my own thoughts and memories connect this research to the writing of my students in a way that stands apart from the analytical gaze I caught myself holding as I poured through their journals.

\section{Introduction: Gender ANd Writing}

Feminist scholars like Jule (2003) and Baxter (2006) agree that messages about gender build an idealized female identity emphasizing complicity and passivity. Basow (2010) has found that female students receive teacher approval for being silent and compliant, and the widespread silencing of female students reflects the internalization of these stories. The silence of female students and the gendered conception of classroom resistance as a verbal act (Basow, 2010) have created a myth that romanticizes the notion of classroom resistance as masculine. Further research by scholars such as Fredericksen (2000) and Elmore and Oyserman (2012) report that this silencing of female students overlooks the alternative ways female students are resisting, and in light of that, overlooks what tools the teacher may provide to female students as channels for resistance.

Journals, as texts that reflect narrative identity, have been historically used by women to rewrite or transform gender stories which interfere with perceptions of the self as strong and capable (Huff, 2003). I found that Jamie, Lisbeth, Cedar, Penny and Serena "wielded the pen" with a similar intent to disrupt and resist in mind. The texts they produced were wedges of space in which resistance was carried out. In each space, I unearthed core commonalities: the positioning of the writing self as storyteller and the splitting of that self necessary to procure an audience for the story to be "told."

I turn the page of her journal, and see this: curling around a sketched thought bubble is the orange body of a model, cut choppily from the pages of a magazine. Glossy. Beheaded. Adorned with the face of a grinning wolf. 
"Tell me how to dress, and I'll bite off your head," the wolf is thinking.

I smile, lean back in my chair.

\section{From Thin Air: Construction of the Gender Story}

"Girl, you ought to stop. Stop thinking.

Stop dreaming. Stop trying to experience

and understand life. Stop living in the

world of the mind."

-from Remembered Rapture: The writer at

work, bell hooks

The message "to stop", spoken to the adolescent bell hooks by her older sister, reflects a historical norm of controlling the identities of women, in order to satisfy the expectation that complicity is a component of female identity (Fredericksen, 2000). "To stop" - to stop resisting and embrace complicity-is one of the many gender stories passed on through this interaction.

Embedded in this warning is a gender story communicating to hooks what the idealized female identity is. The story is subtle and functions according to what is implied-that thinking, dreaming, understanding life, and living in the world of the mind are wrong. It is implied that doing these things is wrong because they stand in opposition to an idealized, unseen female identity not embraced by hooks. Even more deeply coded in the warning is the implication that this unseen, idealized figure would never have tried to live in the way hooks had been trying. That trying, or resisting complicity, apart from being fundamentally wrong, would be futile.

Once internalized, gender stories become a part of who we know ourselves to be (Baxter. 2006). Gender has become a "core identity" (Elmore \& Oyserman, 2012). In this sense, gender matters at school. The identities of students are likely to reflect a struggle to fit into a presupposed gender identity (Fine \& Weis, 2003), or reflect an assimilation of the self into that gender identity (Elmore \& Oyserman, 2012).

Gender stories, layered finely over each other, have built an idealized female identity embodying behaviour that is "ladylike" (Fredericksen, 2000). These stories tell us that apart from being complicit, the correct female identity in the public sphere is nice, cooperative, and polite (Basow. 2010). Baxter (2006) argues that this same ideal female identity holds a passive or non-existent voice in the public sphere, because the female voice exercised in the public sphere is judged as indecent and unfeminine. This unused voice suits the traditional classroom space which values silence and control (Fine \& Weis, 2003). The present day exclusion of female voices from public realms like classrooms relies on this "subtle division of linguistic labour" (Baxter, 2006, p. 8).

\section{Embodying Gender Stories in the Classroom}

Elmore and Oyserman (2012) describe the creative writing classroom as an extension of the public sphere. As such, this space can be seen to mirror the historical silencing of women as female students seek to conform to idealized identities. Fredericksen (2000) argues that female students are rewarded for being "good," working cooperatively and for following the rules. In an effort to perform as feminine and appear unaggressive, female students may avoid verbal participation in class (Butler, 2014). In comparison, Fredericksen (2000) notes that male students 
often verbally dominate the classroom space in group discussions, interrupting female students, and forcing female students to be listeners. Similarly, Jule (2003) argues that female students are positioned to perform the role of the audience to male students. Female students tend to avoid making declarative statements and interrupt male students less, in what Jule (2003) describes as "subconscious subordination" (p. 21) to others in the classroom. Their own relationship to language is changed as a result of their internalized gender stories and, as Jule (2003) notes, women may begin to practice a writing style that is unassertive and consensual, instead of direct and argumentative.

\section{The "Paper Mirror": Journals as Reflections of Narrative Identity}

Gender stories are a specific type of narrative found in a person's narrative identity-their internalized, changing life story (McAdams, 2011). There is often a relationship between expression of the narrative identity, the gender stories embedded in it, and the use of journal writing. Narrative identity, and the gender stories woven into that identity, are reflected in what Hubbs and Brand have coined the "paper mirror" (2005). They argue that just as a glass mirror reflects an image, the journal page reflects the inner worlds of students and their exploration of the self (Hubbs \& Brand, 2005). The act of writing, insist Utley and Garza (2011), allows for fragments of a situation to be melded into a more coherent narrative. Writing represents a calculated effort to express the narrative identity (Moskowitz, 1998). Indeed, McAdams (2011) found an intrinsic need students have to relate their narrative identities to others.

\section{The Historic Use of Journals by Female Writers}

If journals are spaces in which narrative identity is transcribed, it could be assumed that gender stories embedded in that identity would have a long history of replication in the pages of women's journals. However, Huff (2003) insists that journals are historically a site of resistance for women to write their own stories about repressive regimes or ideologies. As noted by Steinitz (2011), the diary reflects the status and situation of the writer, and textualizes the present feelings the writer experiences in the literal moment of writing. Diaries and journals, Huff (2003) argues, focus on the everyday experience. The ordinariness of daily oppression experienced by marginalized members of society is transcribed. For example, Cioux and Calle-Gruber (1997) state "what is most true is naked life." The naked life of woman, the truth that a woman's life is rife with experiences of being silenced, is exposed through the journal in the most frank of terms. It is this naked life-the ordinary life of the personal-that the political mission of the journal draws its life from.

Quite literally, the feminist mantra "the personal is political" can be seen directly in female journal writing. The privileging of personal experience, insists Haronian (1996), is one of the most prominent bequests of feminism's "political-activist heritage" (p. 32). The journal, Wright and Ranby (2009) argue, represents a tradition of the feminist practice because it is an outlet for the female voice that is oppressed in the public sphere. The journal of the female writer, in its careful documentation of inequality and resistance, is a politically charged text. Only through privileging the personal, writing the self in all of its resistance and encounters being silenced, can women's stories stop being untold (Haronian, 1996).

For female writers, journaling is an act of confrontation rather than escape. Cioux and CalleGruber (1997) state that "to write only holds meaning if the gesture of writing makes fear retreat" (p. 25). Writing can be a form of intentional, active resistance (Lanas \& Corbett, 2011). Hooks (1999) claims that writing is a means of confronting reality in order to live life fully. We can think back to hooks' older sister telling her "to stop." Once an order, the message penned by hooks as 
its own newly crafted story has become a source of empowerment. The intent and essence of the order remains the same, but rewritten years later it has become a part of hooks' longer struggle to resist-ironically, now a memory that has spurred her to act, rather than "to stop." For Hooks (1999), writing is only empowering when it is not an act where she deserts "the shadows" (p. 12) that haunt her. In the ten years hooks (1999) spent writing journals, she asserts that she spent the entire time trying to enter these shadows, rather than abandon them.

You're such a geek. Stop thinking.

You're such a book worm. Stop dreaming.

You're such a space cadet, aren't you? Stop living in the world of the mind.

\section{Wielding the Pen: Rewriting Gender Stories}

Through the process of rewriting, female students were subverting stories prescribed to them about their gender that threatened to interfere with their own perceptions of the self as powerful, intelligent, and strong. In rewriting these gender stories, they were altering their narrative identities; they were restructuring the plots of their own lives, making power and strength key themes in their life stories. The students were fashioning themselves as active protagonists (Gubrium \& Holstein, 2009). As Lanas and Corbett (2011) note, students are privy to pursuing resistance in which they are the key actors. By addressing negative stereotypes or harmful gender stories as these actors, Jamie, Lisbeth, Cedar, Penny, and Serena demonstrated an "approach (engagement) response" (Leaper \& Brown, 2008, p.207) to cope with sexism. This approach response empowers the acting individual and reduces their stress by confronting the threat (Leaper \& Brown 2008). Apart from hooks' jumping into the shadows, these students demonstrated a conscious and strategic manipulation of them.

As storytellers, students were engaging in the process of poesis: the affecting of change through imaginative making (Lynes, 2012) by designing new narratives and different conceptions of the self. Poesis in the case of the female students demonstrates an incredibly productive and positive form of resistance (Vetter et al. 2012) giving way for narrative identity to be altered, and perhaps changing the way these students will navigate silencing and marginalization in the classroom or other realms of life. This positive resistance demonstrates how the female students are growing as critical thinkers willing to challenge what they consider unfair. Their resistance articulates transformative learning about their own identities (Vetter et al. 2012).

- Jamie

"I do not have to prove myself to anyone, and I do not feel weak if I need help. If I want to do something, even if it is a 'man's job,' I'm going to do it."

In order to rewrite the gender story, Jamie first confronts the elements within it she finds harmful. She does not, as Cioux and Calle-Gruber (1997) and Hooks (1999) insist, use writing as an escape. Instead, Jamie deliberately assuages the widespread, generalized story that women are not as capable as men. She includes a literal tidbit from the gender story: the phrase 'a man's job.' It is her blatant inclusion of this phrase, rather than a shying away from it that allows her to 
so effectively knock it down. By confronting the sexism she rewrites the gender story for herself, leaving no room for ambiguity of interpretation. She refuses to allow deceptive gender stories to warp her own understanding of herself. Instead, Jamie's perception of herself as capable is sealed, watertight, against any external messages.

Her use of single quotes when writing the phrase 'man's job' implies that, apart from possessing the courage to directly confront and unravel the gender story, Jamie is able to manipulate the concrete language of the story itself. She uses language to orient herself internally and in relation to the social world around her (Orr. 2002), and her opposition to this story becomes a part of her own narrative identity.

\section{- Lisbeth}

"Gender. Scared. She. Mind. Hardship. Excuse. Day after day."

The power of Lisbeth's resistance is drawn from her direct confrontation not of the gender stories themselves, but of a more deeply rooted, intangible fear that surrounds her identity as a woman. Unlike Jamie, who approaches the gender story literally to unravel and remold it, Lisbeth concentrates on how the gender stories affect her and the fear she experiences living as a woman. Lisbeth leaves more to the imagination of the reader; she uses key words which seem to be pulled, floating, from around and within remembrances and experiences that are painful. Though nothing about these memories or experiences (if I can assume that is what she is referencing) are articulated in detail, the reader has an immediate and striking sense of the feelings Lisbeth holds towards those memories or experiences. Lisbeth's ambiguity requests that the reader work a little harder; they must make connections between the keywords she lays out. Though the specifics of her unravelling are deliberately unclear, and are obscured purposefully from the reader in her choice of abstract form, we can understand that Lisbeth is approaching a very palpable sense of fear.

The subversion of the gender story, like the meaning of the phrase itself, is difficult to access. But in its abstraction is a clear and obvious message, as obvious as the feelings of pain that run sharp and deep from the fragment: that despite experiencing fear, and perhaps not knowing the end of it, Lisbeth will continue to survive.

- Cedar

“The whole gender thing is pretty silly. What if I don't want to be any gender? What if I want to be a ghost?"

The innocence and humour in Cedar's musing, although outwardly lighthearted, carry great weight. She uses humour to expose the ludicrousness of having to identify herself according to gender binaries. In questioning "the whole gender thing," Cedar is beginning to undo the idea of living out gender narratives altogether. Her questions, unanswered in the seemingly limitless space of the journal, echo outward.

Whether or not Cedar desires to be a ghost is beyond her point; what she is communicating is that she would like to define herself as adhering to no gender. She would like to be other than. Cedar's "ghost" is a red herring — an oddity - thrown to the reader to catch them off guard from the seriousness of her first query and its shattering power. She understands that her question holds a bracing strength, that it could chink a crack into something she senses to be immense and ordered. Possibly, Cedar feels that her only way to make that fissure is to masquerade her challenge as playful questioning.

The lightness of her query holds a private challenge for her reader-can they perceive Cedar as existing without prescribing to a specific gender? Can Cedar live simply as a ghost? 
- Penny

"But oh, how her spirit is limber

And running through the night"

These are the concluding lines to Penny's poem "Pure Sangre" (Pure Blood), a short poem inspired by Henry Fuseli's painting "The Nightmare." In this painting, a ghoul crouches on the body of an unconscious female figure draped in white. The painting imagines a helpless and unknowing woman who is either asleep or dead, but in any regard, is helpless, immobile, and unable to act. Penny's final lines directly address this female figure. Rather than choose lines from Penny's journal that blatantly confront and unravel gender narratives, I chose to include these lines because they embody an alternative gender narrative for the female subject of the painting and of the poem. Unlike the other students, Penny has melded this alternative gender narrative into the story of her poem's subject. From author to subject moves the act of reimagining the gender story. Penny's personal desire to turn the typical gender narrative inside-out is reflected in her craft and skill as a poet; it is part of the message she leaves the reader. She also hints at the freedom of her subject's being: her subject's spirit, disconnected from her comatose body, is "limber." The image Penny leaves us communicates a sense of personal liberty; the night, dark and endless, holds no boundaries.

- Serena

"Sit like a lady. She gestures to my open legs. Just because I wear a skirt, I have to give up my space? Sit like a lady... I will sit however I want. (And I'll wear lipstick while doing it)."

Serena's heated musing communicates a story in itself: she does identify with the gender presentation of femininity, and it is natural and comfortable for her to do so, but despite her outward adherence to this presentation she will not accept and internalize gender stories as truth. She proves she will not inherit "commodified mythologies" that exist in "the vacuums created by personal or collective amnesia, amnesia that is often solicited or induced" (Wright \& Ranby, 2009, p.62). Her use of underlining, like Jamie's use of single quotes, presents a conscious assertion of power through the text she is creating. The underline seems to be a physical reclaiming of the space that skirt-wearing Serena is sitting in. Her use of ellipsis represents the space taken by her growing frustration. In the pause of rest between words, I can feel her frustration expand, life-sized and wide-legged. She attacks the gender narrative that women must assume as little space as possible in the public sphere and that they must always accommodate and make room for others. Like Cedar, Serena questions, incredulously, why she must give up her space. Like hooks, Serena relates an instance of being policed by another woman.

Serena's humorous tone calls attention to her supposedly paradoxical gender presentation. She wears lipstick and a skirt, as a woman is expected to do, while taking up space, as a man is expected to do. Her promise to "wear lipstick while doing it" might remain confusing and unnerving for the individual who directs her to cross her legs, but she makes it clear that she will do what she wants.

The only words scribbled on the white page: I am a writer. I can write beauty, desire, destruction, sadness.

With my own pen poised in hand, I think to myself: revelry. Revelry and resistance. 


\section{Writing as a Place: The Journal as a Space of Resistance}

In each journal, language is used to create an individual space (Knutson, 2011), allowing for the expression of identity. The journal, as a space of resistance, is valuable for female students because of its limitless and infinite form (Steinitz, 2011); its blank pages make it an attractive space for leg stretching, or even swagger. Wright and Ranby (2009) harken to Virginia Woolf's concept of "A Room of One's Own" when describing the journal as a specific space. They perceive Woolf's metaphor as indicative of the psychic space in which women represent themselves (Wright \& Ranby, 2009).

Lanas and Corbett (2011) argue that a "third space" is needed for students to express themselves in the school environment - one that is not fully public or fully private. The journal, as a private text often shared with the teacher, saddles the public and private worlds. It is the liminal space in which teachers may hear the voices of resisting students. This same space provides refuge for students seeking to express not their "academic voices," but their "own voices." Fine and Weis (2003) believe that the educational system has trained students to undergo "linguistic violence" as they sift out personal strains of themselves from their writing to produce more formal, scholarly material. The journal can be a place where students resist the violence of this separation.

You can write about whatever you want, I say to the class. Just remember: write without restraint.

Anything we want? The student isn't smiling.

Yes, anything.

But I'm cringing inwardly inside. I'm a little afraid to be so close to the pain of others.

\section{Written out, Written in: The Paradoxical Nature of Journals}

The journal paradoxically holds both the rewritten gender stories, and the sources of that resistance. Journals become territories where divisions coexist (Knutson, 2011). Written in the journals are both memories and thoughts triggering shame and the resulting empowerment from it. In rewriting harmful stories, the students are confronting and acknowledging the shame and pain that brought them to resist and rewrite in the first place. Shame, Brown (2012) argues, derives its power from being unspeakable. Hooks (1999), who once faced shame at being admonished "to stop," uses language and story to bring light to her shame to destroy it, as do Jamie, Lisbeth, Cedar, Penny and Serena. The students are able to resist by knowing and exploring what is causing them to hurt. Hooks (1999) echoes this view, stating: "only in fully knowing the wound could I discover ways to attend to it" (p. 13). Cioux and Calle-Gruber (1997) also insist that the shame or pain confronted in writing can be likened to a physical open wound, and that although "we are terribly afraid of looking at it... we are perhaps the only ones capable of looking at it" (p. 25). Shame holds a sacred place in these journals as the impetus of resistance.

Jamie, in her assertion that she will do a "man's job," is confronting the shame that has been veiled upon her-doubt that she may not do as good a job as a man or doubt that certain jobs will not be easily available to her because of her gender. The shame is unwritten, but it is still present 
in-between the lines of her written fight. Lisbeth, who expresses and writes her fear concretely, leaves the detail of her fear to the imagination of the reader. Like Jamie, Lisbeth's journal holds both resistance and the source of her resistance.

Cedar's journal is an exception to this concrete or implied inclusion of shame and pain. Her humour attempts to bypass or exclude the source of her resistance entirely. Unlike Jamie and Lisbeth, pain or shame is difficult to detect in her writing. Penny's writing, too, upon first inspection appears only to focus on the freedom of her figure, but perhaps this is because the source of resistance is more deeply embedded in her crafting of a deliberately free subject.

\section{The Self as Storyteller}

Every student, with the exception of Penny, uses first person "I" statements. The use of "I" is, in simplest terms, the voice of the "self" (Blodgett, 1996). Through privileging the "I," both she and Jule (2003) insist, feminist writers have traditionally resisted definition by male authority as they position themselves at the story's center. The "II" focusing on the subjective experience of the writer, allows for the recreation of the self on the page, "subverting the power of fixed representations of selfhood" (Wright \& Ranby, 2009, p.57).

Use of the "I" naturally positions the students as owners and creators of the stories in their journals; the students become active agents in producing the meaning of their self-identities (Utley) \& Garza, 2011). In turn, their identities are shaped through telling the story (Faircloth, 2012). As crafters of the stories, the students' selves are validated as the authority. As the storytellers, each of the students express their subjective desires and move to reclaim their lives (Haronian, 1996). We see Jamie and her determination: her making of an unspoken promise to never feel weak. We see Lisbeth's pain and her survival, Cedar's ghost, Penny's subject running not from the night, but through it, and finally, the grit of Serena, biting back. What we never see is the stillness of acquiescence. There is only movement as the stories and stereotypes and assumptions are undone, twisted this way and that, transformed into entirely different creations. Indeed, argue Gubrium and Holstein (2009), the substance of a story is elastic, molded into different shapes and directions by its teller.

By positioning themselves as the storytellers, students construct a storyteller-listener dynamic. One could assume that the very power of the story lies in its relationship with a listener: that a listener validates the story and must exist for the story to be heard (Georges, 1990). Considering the longstanding tradition of the journal as private, critics could argue that the storyteller-listener dynamic is rendered powerless. But what happens when the voices of the storytellers, silenced and unheard in the classroom, boom to life in the journal? Are those silenced voices simply relegated, controlled and quiet, to the private sphere from which they are assumed to belong?

Huff (1989) argues that journals, though separate entities sitting alone on desks or shoved deep in book bags, connect women writers to "our past selves, our projected identities, and our roots in a collective yet differentiated women's past" (p. 6). She argues that feminism as a social practice makes connections and establishes community between separated parts of existence (Huff. 1989). Though the stories in the journal may not be directly shared with a listener or audience, they are crafted from and are part of a shared experience. The " $\mathrm{I}$ " written by these female students is not singular, but plural. The "I" is drawn from the identities of all female students and represents the shared experience of asserting the self in a private space (Blodgett, 1996). Through language-the tiny "I" scrawled on the page-we can connect ourselves to other selves (Orr. 2002).

Though I assume that Jamie, Lisbeth, Cedar, Penny, and Serena would not have shared their journals with each other, all five stories are connected by the shared desire to engage in rewriting. Each of these students are part of a communal collective as storytellers who are seeking to alter 
"generational narratives" (Huff, 1989). In this sense, the ideal of the "solitary writer" stands to be interrogated, as students join themselves to imagined communities of voices (Huff, 1989). The assertive words of these students are buoyed by the knowledge that they are not alone. Their words are backed by the strength of others who wrote before them and for them.

A no-send letter

Dear students,

It has been over six months, and I'm still studying the writing in your journals. I've seen some very sharp claws, and read some very soft words.

Ms. L

XIII. The Two Selves

As storytellers without "listeners," each of the students wrote to their "selves" to make possible the existence of the storyteller. The voice of the storyteller and the presence of a listener-and the belief that both are legitimate-is vital for rewriting gender stories. At the same time as the students were holding their pens, scribbling in the pages, they were, in that moment of storytelling, also acting as listener. In an instance of complete self-sufficiency, students had already procured an audience to legitimize their newly crafted gender stories. This is where the power of the "individual" experience of journaling lies: in its ability to simultaneously call to and speak to the other self. Storytelling represents an instinct to connect and communicate with others (Faircloth 2012). We see this movement to connect in the journals as students call to a past, present, and future female consciousness, and we see it further in the journals of Jamie, Lisbeth, Cedar, Penny, and Serena, when their written words call directly to their pen-wielding selves.

- Lisbeth

"Do not be a prisoner to the confines you make for yourself. Paint a reality that satisfies you."

Lisbeth directly instructs herself to both remain a free individual, and to create a life that makes her happy. The actively journaling Lisbeth stands apart from the Lisbeth who lives at the peril of imprisoning herself. The actively journaling Lisbeth seems to hold power to warn of impending dangers that she believes are threatening to her freedom.

- Penny

“Dear Penny, I'm excited to be you. I'm immensely intrigued about who you will become or who you are."

Here, the divide in the two selves is present yet again. The actively writing self is speaking to another self who seems to exist in an unreachable space. Penny's words-her actions as storyteller-create a space in which the writing self can acknowledge the existence of the 
other. Her journal is a place where the two selves can meet. In speaking to herself, Penny calls out, and though her call goes unanswered-she is not given any answers as to who she will become-she can hold her hand up to the paper mirror and feel her palm rest not against paper, but the skin of herself.

- Serena

"I'm really sorry. I mean, I know. You're a mess right now. You find yourself eyeing weapons of mass destruction. But please, find other ways to love yourself."'

As much as Serena is writing to herself, there seems to be space between the troubled Serena that is being addressed and the Serena who presents herself as strong enough to speak to the person sitting in shadow, imploring the other to love themselves. The actively writing Serena, the all-powerful storyteller, is positioned as the emotionally able person who is needed at that instance to support the figure eyeing those weapons.

\section{The Divide in Selves: The Reflection in the Journal as the "Other"}

When students look into the "paper mirror," they see a reflection of themselves-they see an "other." The stories they tell create "selves which produce more selves" (Faircloth, 2012). Through rewriting stories, students create the other stronger, happier, or freer self. For Lisbeth, an imprisoned self is envisioned, but a free self is imagined as rescuer. Penny's "other" is a mystery, remains unidentified or outlined in any way, and because of that, holds infinite possibilities for growth. Like her figure running through an endless night, her "other" adheres to no limits. Serena's "other" is her lifesaver that is drawn from the same fiery strength that sits, knees apart, with lipstick and a skirt on. Despite seeing Serena act powerfully in two circumstances: her assertion of physical space, and her rescue, we are privy to another self- one that is hurting, messy, and holds no leg stretching bravado or ability to rescue.

At the same time as we stand separate from our reflections in the paper mirror, we are our reflections. The actively writing self is our listening self and is our audience. Lisbeth is both imprisoned and free, Serena's rescuer and the self eyeing weapons of mass destruction are the same person, and Penny is both searching and found.

Cioux and Calle-Gruber (1997) claim they are not separate from their own writing and that they only become themselves in the act of writing. The same concept applies to the experience of the journaling students. By adopting the role of storyteller, the students speak to themselves, but holding that role is only possible if there is a distinction or divide made in the self-someone must be spoken to.

I'm facing away from the class, scrawling "I live for the blank - " on the board, almost done. My favourite quote by author Lisa Unger. I have so many expectations for the class and plans for what the next nine weeks will be like. But first, I have to turn around and introduce myself. Deep breath.

Later, a student will visit the guidance counselor, tell them they think I will teach writing too much like a "girl." They will receive permission to take the class by correspondence. For the next nine weeks of class, I skip over their name when filling out the attendance sheet. Week after week, the unchecked boxes on the sheet merge into a single length of empty white space 
The Arbutus Review • Fall $2015 \bullet$ Vol. 6, No. 1

\section{Tracing the Shape of Absence: The Lack of Male Participants}

Lacuna

1. A cavity or depression in the matrix of bone

2. An extended silence in a piece of music

3. A missing section of manuscript or portion of text; a lexical gap

—The English Encyclopedia, 2015

When I turned from the journals of my female students to the journals of my male students, that loud and triumphant music of resistance quieted. Amidst the many voices shouting out, whispering, and demanding, I sensed a great silence underlying it all. I felt a very palpable ache of something missing. Gubrium and Holstein (2009) argue that to fully revere the presence of specific narratives, the listener must also consider instances where they are withheld, what he defines as "narrative silencing" (p. 53).

In school, male students often embody traits that are considered inappropriate, like disobedience and defiance (Henderson, 2008). To align themselves with identities of hegemonic masculinity, male students are pressured to assume "performance practices" (Dalley-Trim, 2006, p.26). They, too, are pressured to construct themselves as specific subjects, and in doing so, become gendered actors in the classroom (Davis, 2015). By acting the parts defined for them and playing tough, refusing to affirm authority, shouting out and interrupting (Dalley-Trim, 2006), male students are protecting themselves from having to "correct" their identities. Apart from having to play this role, strong academic performance may suggest to a male student that they have a compliant identity (Butler. 2014).

The absence of completed and handed in journals is the reproduction of countless gender stories acting "to stop" the male students from dismantling idealized components of male identity. The order given to hooks to stop thinking, stop dreaming, and stop living in the world of the mind takes on an added level of irony-it is a patriarchal order holding the same purpose for men as it does for women: to manage the self.

In the journals of Seamus, Alistair, and Perry, I observed that the concept of gender was never directly and blatantly tackled. Gender was not transcribed through their narrative identities, and the journal was not used as a medium in which to confront these issues. Somewhere in the space between pen and page the motion to physicalize musings on gender dissipated, or perhaps it was never born in the first place. It is possible that for the male students, the journals presented a means of escape from contemplating gender and identity. Perhaps these students needed to do what hooks argues so ardently against.

For the male students, the very act of journaling was resistance to performing a hyper-masculine identity in the classroom Davis (2015). By engaging in the journaling project, male students were actively adopting what they may have perceived to be a more feminine and less powerful position in school (Henderson, 2008). Finishing the assignment and demonstrating compliancy (Leaper \& Brown, 2008), dedicating themselves to a fundamentally uncompetitive project (Butler, 2014), 
and forgoing the "tough" guy persona (Dalley-Trim, 2006) to engage in emotional exploration are elements of that resistance. The male students who chose not to hand their journals in were perhaps aiming to protect themselves from punishment on behalf of their peers (Dalley-Trim, 2006). They, too, were protecting their identities from the possibility of disintegration as vehemently as Jamie, Lisbeth, Cedar, Penny, and Serena.

\section{Recommendations for Future research and Practice}

I suggest that future researchers should analyze a larger number of male journals to observe whether any address gender and identity through writing, and to compare any commonalities or differences potentially shared with female students who rewrite. Facilitating the inclusion of male students in the journaling process would require the non-participatory students to consider that they can have multiple subjectivities or identities (Henderson, 2008) that, although contradictory, do not negate the existence of the other. In this sense, male students would need to believe that there are a range of ways to "do" masculinity (Dalley-Trim, 2006).

But the resistance of male students who chose not to participate, and the resistance of Seamus, Alistair, and Perry to exploring gender through writing, may be the natural first step (Ergun. 2013) towards one day engaging in a journaling project, or one day using the journal to explore gender and identity. The lack of rewritten gender stories on behalf of the participating male students, their avoidance of approaching the topic of gender, and their lack of participation in the journaling project and study highlight how strongly socialized ideas about identity are thriving in the classroom, and how they may control the outcomes of a potential project or request suggested on part of the teacher.

The fact that only a minority of participating female students used their journals to rewrite gender stories points to multiple possibilities: these female students may not feel that gender stories or stereotypes are separate from their own identities as Jamie, Lisbeth, Cedar, Penny, and Serena do. They may identify with genders stories as intrinsic to who they are. That same shame, pain, and frustration that Jamie, Lisbeth, Cedar, Penny, and Serena experience and seek to rewrite may not be felt as keenly and may require less of a need for the students to transform or redefine it. I believe, however, that it is more likely the female students who chose not to rewrite gender stories are resisting in a multitude of complex and interconnected forms not yet unearthed.

When Fredericksen (2000) states that "educators make a serious mistake if they believe female silence means acquiescence," (p. 304) she indicates that female students are strategizing and experimenting with multiple forms of resistance. She is pointing to the craftiness of female students. Though female students may not as frequently verbalize their resistance due to ingrained politeness (Fredericksen, 2000), and they may not use journaling as a primary means of expressing resistance, it would be unwise to assume that they do not resist in any other way. Teachers must acknowledge that the individual resistance of female students will be presented differently than that of male students and of other female students. We must provide them with options to express and channel that resistance in a specific space.

If teachers expand their conception of female resistance and focus not only on the silencing and marginalization of female students, but on the creative way these students might choose to resist, they can take into account how specific assignments may either limit or unlock possibility for a student to explore gender in relation to their identity. To envision the journal as a space to nourish female resistance is simply a starting point. My study holds its importance in highlighting the need for teachers to be attuned to moments in text or in the classroom where student resistance is expressed, to recognize it, and to meet that resistance with flexibility and creativity. 


\section{Concluding Thoughts}

Brown (2012) believes that if an individual "owns" their story, they alone hold the power to rewrite its ending. Haronian (1996), however, questions whether or not writers should be rewriting the endings of stories at all. She argues that female writers need to envision stories that have expanded narrative models without endings because she believes that "the end of a story marks not only the end of its tale, but of the teller" (Haronian, 1996, p. 23). Thinking back to my students, I have to question: will their rewritten stories translate into practice beyond the journal page, or will they simply "end"? Will the words of bell hooks' older sister "to stop" end up becoming the fate of my female writing students?

I will never know if Jamie will move through life doing every "man's job" she encounters, and perhaps one day Serena's indignant legs will cross neatly, one over the other. I acknowledge that it is not possible to completely assess the extent to which the resistance demonstrated in their journals is brought forth in their individual lives. To trace the lasting impact of rewriting gender stories and to investigate how resistance carries on beyond the written text, into action, are two inquiries that merit future research.

When I picked up and flipped through the journals, I found I was studying living text: stories that I could not pick up and hold so easily, whose writers were constantly shifting as they rewrote the self through their own imaginative making. A self-induced poesis of the mind and body. Writing this paper, I found myself submerged in the poesis of my students, far below the words on their pages, in a place where I could hear their voices and envision their subjects. What drew me to this study was the promise to analyze the life of the words on those pages-the intent behind tone, the fashioning of subjects, the use of diction. But the journal, I learned, leaves as much out as is included, is as much a fiction as it is truth, and is, simply, a performance of naked life. Despite my examination of the text and analysis of subtext, I seemed to pull from the writing what I already knew, and what I saw in myself as an adolescent journal writer-a single thread, holding fast: the will to fight.

I finish combing through the journals. Flex my fingers. Strewn around me on the floor are piles of ratty Hilton notebooks, one thick leather journal. A clump of graph paper stapled together at the spine. An embossed, hardcover diary.

The tea in my mug is cold. I open my laptop up and minimize the pages of scholarly journals, the academic databases and my citation guide, leaving a single blank document. Then I stretch out to pick up the closest journal in arm's reach.

Beware...

\section{REFERENCES}

Basow, S. A. (2010). Gender in the classroom. In Handbook of gender research in psychology (pp. 277-295). Springer. http://dx.doi.org/10.1007/978-1-4419-1465-1_14

Baxter, J. (2006). Speaking out: The female voice in public contexts. Palgrave Macmillan. http://dx.doi.org/10.1057/9780230522435

Blodgett, H. (1996). Writing selves: Contemporary feminist autography (review). Biography, 19(4), 435-437. http://dx.doi.org/10.1353/bio.2010.0736 
Brown, B. (2012). Daring greatly: How the courage to be vulnerable transforms the way we live, love, parent, and lead. New York, NY: Gotham Books.

Butler, R. (2014). Chapter one-motivation in educational contexts: Does gender matter? Advances in child development and behavior, 47, 1-41. http://dx.doi.org/10.1016/bs.acdb.2014.05.001

Cixous, H., \& Calle-Gruber, M. (1997). Hélène cixous, rootprints: Memory and life writing. Psychology Press. http://dx.doi.org/10.4324/9780203443590

Dalley-Trim. (2006). 'Just boys being boys'? Youth Studies Australia, 25(3), 26-33.

Davis, I. (2015). Stories of men and teaching. In A new narrative approach to understanding maculinity and education (pp. 39-54). Springer Singapore. http://dx.doi.org/10.1007/978-981-287-218-0_4

Elmore, K. C., \& Oyserman, D. (2012). If we can succeed, I can too: Identity-based motivation and gender in the classroom. Contemporary educational psychology, 37(3), 176-185. http://dx.doi.org/10.1016/j.cedpsych.2011.05.003

Ely, M. (1997). On writing qualitative research: Living by words (No. 12). Psychology Press.

Ergun, E. (2013). Negotiating the geopolitics of student resistance in global feminisms classrooms. Feminist Teacher, 23(2), 83-104. http://dx.doi.org/10.5406/femteacher.23.2.0083

Faircloth, B. S. (2012). "Wearing a mask" vs. connecting identity with learning. Contemporary Educational Psychology, 37(3), 186-194. http://dx.doi.org/10.1016/j.cedpsych.2011.12.003

Fine, M., \& Weis, L. (2003). Silenced voices and extraordinary conversations: Re-imagining schools. Teachers College Press.

Fredericksen, E. (2000). Muted colors: Gender and classroom silence. Language Arts, 301-308.

Georges, R. A. (1990). Communicative role and social identity in storytelling. Fabula, 31(1-2), 49-57. http://dx.doi.org/10.1515/fabl.1990.31.1-2.49

Gubrium, J. F., \& Holstein, J. A. (2009). Analyzing narrative reality. Sage. http://dx.doi.org/10.4135/9781452234854

Haronian, M. J. (1996). When the teller ends with the tale: the story as metaphor for feminist agency. Women and Language, 19(1), 32.

Henderson, R. (2008). A boy behaving badly: Investigating teachers' assumptions about gender, behaviour, mobility and literacy learning. The Australian Journal of Language and Literacy, 31(1), 74-87.

Hooks, B. (1999). Remembered rapture: The writer at work. Henry Holt.

Hubbs, D. L., \& Brand, C. F. (2005). The paper mirror: Understanding reflective journaling. Journal of Experiential Education, 28(1), 60-71. http://dx.doi.org/10.1177/105382590502800107

Huff, C. (1989). "That profoundly female, and feminist genre": The diary as feminist practice. Women's Studies Quarterly, 6-14.

Huff, C. (2003). Towards a geography of women's life writing and imagined communities: An introductory essay. Prose Studies: History, Theory, Criticism, 26(1-2), 1-16. http://dx.doi.org/10.1080/0144035032000235783

Jule, A. (2003). Gender, participation and silence in the language classroom. Palgrave Macmillan. http://dx.doi.org/10.1057/9780230596627 
Knutson, E. M. (2011). Writing in between worlds: Reflections on language and identity from works by Nancy Huston and leila sebbar. In Symposium: A quarterly journal in modern literatures (Vol. 65, pp. 253-270). http://dx.doi.org/10.1080/00397709.2011.628589

Lanas, M., \& Corbett, M. (2011). Disaggregating student resistances analyzing what students pursue with challenging agency. Young, 19(4), 417-434. http://dx.doi.org/10.1177/110330881101900404

Leaper, C., \& Brown, C. S. (2008). Perceived experiences with sexism among adolescent girls. Child Development, 79(3), 685-704. http://dx.doi.org/10.1111/j.1467-8624.2008.01151.x

Lynes, K. G. (2012). Poetic resistance and the classroom without guarantees. Annual Bibliography of English Language and Literature, 15(3).

McAdams, D. P. (2011). Narrative identity. In Handbook of identity theory and research (pp. 99-115). Springer. http://dx.doi.org/10.1007/978-1-4419-7988-9_5

Moskowitz, C. (1998). The self as source: Creative writing generated from personal reflection (F. Sampson, Ed.). Jessica Kingsley Publishers.

Orr, G. (2002). Poetry as survival. University of Georgia Press.

Steinitz, R. (2011). Time, space, and gender in the nineteenth-century british diary. New York: Palgrave Macmillan. http://dx.doi.org/10.1057/9780230339606

Utley, A., \& Garza, Y. (2011). The therapeutic use of journaling with adolescents. Journal of Creativity in Mental Health, 6(1), 29-41. http://dx.doi.org/10.1080/15401383.2011.557312

Vetter, A., Reynolds, J., Beane, H., Roquemore, A. R., \& Shepherd-Allred, K. (2012). Reframing resistance in the English classroom. English Journal, 102(2), 114-121.

Wolgemuth, J. R. (2014). Analyzing for critical resistance in narrative research. Qualitative Research, 14(5), 586-602. http://dx.doi.org/10.1177/1468794113501685

Wright, J., \& Ranby, P. (2009). 'composing myself on paper': Personal journal writing and feminist influences. Women's Studies Journal, 23(2), 57-67. 